\title{
PROFIL KEBUGARAN JASMANI ATLET PENCAK SILAT PPLP KALIMANTAN SELATAN
}

\author{
Lazuardy Akbar fauzan $^{1}$, Edwin Wahyu Dirgantoro ${ }^{2}$ \\ Program Studi Pendidikan Jasmani \\ Fakultas Keguruan Dan Ilmu Pendidikan, Universitas Lambung Mangkurat \\ Lazuardy.fauzan@ulm.ac.id
}

\begin{abstract}
ABSTRAK
Kebugaran jasmani merupakan salah satu unsur penting dalam peningkatan prestasi atlet. Atlet yang memiliki kebugaran jasmani yang baik tidak akan mengalami kelelahan yang berarti, baik dalam setiap latihan maupun dalam pertandingan. PPLP merupakan program dari Kemenpora (Kementerian Pemuda dan Olahraga) untuk membentuk talenta berbakat yang berprestasi di usia muda. Bekerjasama dengan Dinas Pemuda dan Olahraga di setiap provinsi dalam pembinaannya. Tujuan dari penelitian ini adalah untuk mengetahui tingkat kesegaran jasmani atlet pencak silat PPLP Kalimantan Selatan. Penelitian ini merupakan penelitian deskriptif kuantitatif dengan menggunakan metode survey dengan teknik tes dan pengukuran. Teknik pengambilan sampel pada penelitian ini menggunakan teknik total sampling. Sampel dalam penelitian ini adalah seluruh atlet pencak silat PPLP Kalimantan Selatan yang berjumlah 7 orang. Intrumen tes yang digunakan dalam penelitian ini adalah instrumen tes atlet dari kemenpora edisi tahun 2014. Teknik analisis yang dilakukan adalah mengunakan frekuensi ke dalam bentuk persentase.

Hasil penelitian ini menunjukkan bahwa tingkat kesegaran jasmani atlet pencak silat PPLP Kalimantan Selatan adalah 1) Kriteria index masa tubuh atlet pencak silat PPLP Kalsel sebanyak 86\% masuk kategori ideal, 2) tingkat kecepatan (speed) atlet pencak silat PPLP Kalsel sebanyak $29 \%$ masuk kategori sangat baik, 3) tingkat kelincahan atlet pencak silat PPLP Kalsel sebanyak 86\% masuk kategori sangat baik, 4) kemampuan daya ledak otot (muscle explosive) atlet pencak silat PPLP Kalsel sebanyak 57\% masuk kategori sangat baik, 5) kekuatan otot lengan (power) atlet pencak silat PPLP Kalsel sebanyak 29\% masuk kategori sangat baik, 6) kekuatan otot perut atlet pencak silat PPLP Kalsel sebanyak $86 \%$ masuk kategori sangat baik, dan 7) kemampuan daya tahan (endurance) atlet pencak silat PPLP Kalsel sebanyak 49\% termasuk kategori sangat baik.
\end{abstract}

Kata Kunci: Kebugaran jasmani, Pencak silat, PPLP

\section{ABSTRACT}

Physical fitness is an important element in increasing athlete's performance. Athletes have good physical fitness doesnt fatigue in trainning and competition. PPLP is a program from the Indonesian Ministry of Youth and Sports (Kemenpora) to form young talented. Its implementation In cooperation with the Youth and Sports Department in each province. The purpose of this research was to determine the level of physical fitness pencak silat athletes of PPLP South Kalimantan. This research is a quantitative descriptive study using a survey method with test and measurement techniques. The sampling technique in this research used a total sampling technique. The sample in this research is 7 pencak silat athletes. The instrument test used in this research is the athlete instrument test from Kemenpora 2014 edition. The analysis technique used frequency percentage.

The results of this research are 1) The criteria for body mass index athletes as $86 \%$ are the ideal category, 2) Speed performance athletes as 29\% are the very good category, 3) Agility performance athletes as $86 \%$ are the very good category, 4) The muscle explosive power athletes as $57 \%$ are the very good category, 5) The muscle strength athletes as $29 \%$ are very good category, 6) The abdominal muscle athletes as $86 \%$ are the very good category, and 7) The endurance performance athletes as $49 \%$ are the very good category.

Key words: Physical fitness, pencak silat, PPLP

Dipublikasikan Oleh :

UPT Publikasi dan Pengelolaan Jurnal

Universitas Islam Kalimantan Muhammad Arsyad Al-Banjari Banjarmasin 


\section{PENDAHULUAN}

Kesegaran jasmani merupakan kemampuan fisik seseorang untuk melaksanakan tugasnya sehari-hari secara efektif dan efisien dalam waktu yang relatif lama tanpa mengalami kelelahan yang berarti (Departemen Pendidikan dan Kebudayaan, 1996). Sebelum diterjunkan kedalam gelanggang pertandingan, seorang atlet harus sudah berada dalam suatu tingkat kesegaran jasmani dan tingkat fitness yang baik untuk menghadapai intensitas kerja dan segala macam yang bakal dihadapinya dalam pertandingan (Harsono, 1988). Menurut (Departemen Pendidikan Nasional, 2000) setiap pelatih harus meningkatkan dan membina tingkat kesegaran jasmani para pemainnya. Apabila seorang atlet tenis lapangan akan mencapai suatu prestasi optimal, maka harus mempunyai kelengkapan pengembangan fisik, teknik, mental, dan kematangan juara. Menurut (Djoko Pekik Irianto, 2004), kesegaran digolongkan menjadi (1) Kesegaran Statis yaitu keadaan seseorang yang bebas dari penyakit dan cacat atau disebut sehat, (2) Kesegaran Dinamis yaitu kemampuan seseorang bekerja secara efisien yang tidak dapat memerlukan keterampilan khusus, misalnya berjalan, berlari, melompat, mengangkat, (3) Kesegaran Motoris yaitu kemampuan seseorang bekerja secara efisien yang menurut ketrampilan khusus. Seorang olahragawan dituntut memiliki kebugaran motoris agar dapat berprestasi optimal karena dalam kesegaran motoris sangat erat hubungannya dengan efektifitas gerak masing-masing cabang olahraga. Atlet harus menguasai efektifitas gerak sesuai dengan cabang olahraganya masing-masing untuk dapat mencapai prestasi yang optimal. Penguasaan efektifitas gerak ini atau kesegaran motoris diperolah dari disiplin latihan yang baik dan kemampuan seorang pelatih menganalisis aspek kebugaran jasmani apa saja yang dibutuhkan dalam masing-masing cabang olahraga.

Pencak silat adalah seni bela diri dari Indonesia yang menggunakan unsur seni dan digabungkan dengan kemampuan beladiri seseorang, sehingga mendapatkan gerakan-gerakan yang indah dan bertenaga (Dwi Bagus Subroto dan Achmad Rizanul Wahyudi, 2017). Pencak silat juga sangat populer di negara-negara di wilayah Asia Tenggara. Pencaksilat awalnya menjadi tradisi kesenian deladiri yang tersebar melalui tradisi Melayu Nusantara. Seiring berjalannya waktu, melalui interaksi dan transfer budaya, pencak silat menyebar di negaranegara Asia hingga keseluruh dunia. Pencak silat menjadi olahraga beladiri yang sudah dipertandingkan secara resmi dalam event-event dari tingkat daerah sampai knternasional. Kejuaraan tersebut antara lain PON, Sea Games, dan kejuaraan dunia pencak silat.

Pencak adalah permainan (keahlian) dalam rangka mempertahankan diri menggunakan kepandaian mengelak, menangkis, dll (Hasan Alwi, 2008). Pencak adalah gerakan langkah menghindar yang mengandung keindahan yang disertakan gerakan yang mengandung berunsur komedi. Pencak bisa dipertontonkan menjadi sarana hiburan (Sucipto, 2001). Sedangkan silat merupakan unsur gerakan teknik bela diri menyerang, menangkis, dan mengunci yang tidak dapat diperagakan di depan umum. Pendapat yang sama menurut Mr. Wongsonegoro ketua IPSI yang pertama dalam (Sucipto, 2001) mengatakan bahwa pencak merrupakan gerakan serang bela, berupa lari dangan irama yang mengandung peraturan adat kesopanan tertentu, yang dapat dipertunjukan di depan umum. Silat merrupakan inti sari dari pencak, yakni kemahiran untuk membela diri atau perkelahian mati-matian yang tidak bisa dipertunjukan di depan umum.

Setiap cabang olahraga memiliki karakteristik gerak yang berbeda. Pencak silat dalam gerakannya mengkombinasikan unsur-unsur serangan, tangkisan, kuncian, pukulan, tendangan, dan bantingan. Hal ini akan berkaitan dengan komponen-komponen kondisi fisik yang dominan sesuai dengan cabang olahraga yang bersangkutan. Setiap cabang olahraga mempunyai komponen kondisi fisik yang di gunakan dalam cabang olahraga tersebut. Adapun komponen kondisi fisik pencak silat yang dominan antara lain: kekuatan, daya ledak otot tungkai, kelincahan, kecepatan, kelentukan, daya tahan, dan koordinasi mata dan tangan (Habibuddin Muhammad, 2013).

Menurut pendapat (Khairul Hadziq, 2017) komponen kondisi fisik dibagi menjadi dua kategori yaitu kebugaran jasmani yang berhubungan dengan keterampilan dan kebugaran jasmani yang berhubungan dengan kesehatan. Tingkat kebugaran jasmani yang dimiliki oleh seseorang dipengaruhi oleh beberapa faktor, menurut (Suharjana, 2013) faktor-faktor tersebut yaitu sebagai berikut (1) Usia. Setiap tingkatan usia mempunyai kaitan erat dengan tingkat kebugaran jasmani. Dokter Sundardas dalam bukunya yang berjudul "The asian woman"s guide to health beauty \& vitality" yang diterbitkan tahun 2001 menyataka bahwa kebugaran jasmani anak akan meningkat sampai maksimal pada usia 25 tahun dan kemudian setelah usia mencapai 30 tahun akan mengalami penurunan kapasitas fungsional dari seluruh tubuh, kira-kira sebesar $1 \%$ tiap tahun, tetapi bila rajin berolahraga penurunan ini akan terjadi sebesar 0,1\% pertahun (http://www.femina.co.id, 2013), (2) Jenis Kelamin. Tingkat kebugaran jasmani yang dimiliki oleh siswa putra umumnya lebih baik apabila dibandingkan dengan siswa putri. Hal ini tersebut karena karakteristik siswa putra lebih banyak melakukan aktifitas dibandingkan dengan siswa putri. Sampai memasuki masa pubertas, umumnya kebugaran jasmani anak laki-laki hampir sama dengan anak 
perempuan, tapi setelah pubertas, anak laki-laki biasanya memiliki perkembangan nilai yang jauh lebih besar, (3) Genetik. Genetik memberikan dampak terhadap kapasitas jantung paru, hemoglobin (sel darah merah), postur tubuh, otot, dan obesitas.

PPLP merupakan Pusat Pendidikan Latihan Pelajar. PPLP merupakan program kerja dari Kemenpora (Kementerian Pemuda dan Olahraga) untuk membangun talenta-talenta yang berprestasi di usia muda. Setiap Dinas Pemuda dan Olahraga di setiap provinsi kini telah menyelenggarakan PPLP untuk menampung para atletatlet yang memiliki potensi di berbagai cabang olahraga (cabor). Atlet-atlet muda yang tergabung dalam program PPLP ini akan dibina sesuai dengan cabang olahraganya. Mereka akan dilatih secara intensif dan perkembangannya selalu dipantau pelatih masing-masing cabor. Selama mengikuti program PPLP, para atlet akan digembleng untuk mencetak prestasi baik dalam kejuaraan daerah hingga ke tingkat nasional. Berdasarkan Peraturan Menteri Pendidikan Nasional No. 34 tahun 2006 tentang pembinaan prestasi peserta didik yang memiliki potensi kecerdasan dan/atau bakat istimewa, yang didalamnya mencakup bidang iptek, estetika dan olahraga. semua calon atlet yang akan bergabung dalam pplp harus mengikuti seluruh tahapan seleksi yang diadakan oleh masing-masing daerah. Tujuan pembinaan prestasi peserta didik yang memiliki potensi kecerdasan dan/atau bakat istimewa melalui program PPLP yaitu untuk (1) mendapatkan peserta didik yang berhasil mencapai prestasi puncak di bidang ilmu pengetahuan dan teknologi, estetika, dan/atau olahraga, pada tingkat satuan pendidikan, kabupaten/kota, provinsi, nasional, dan internasional, (2) memotivasi sebanyak mungkin peserta didik pada umumnya untuk juga ikut bersaing mencapai prestasi optimal sesuai dengan potensi dan kekuatan masing-masing, sehingga pembinaan tersebut tidak hanya sekedar mampu menghasilkan peserta didik dengan prestasi puncak, tetapi juga meningkatkan prestasi rata-rata peserta didik, (3) mengembangkan budaya masyarakat yang apresiatif terhadap prestasi di bidang pendidikan. Tanggung jawab pelaksanaan PPLP diserahkan kepada masing-masing satuan pendidikan, pemerintah kabupaten/kota/provinsi sesuai kewenangannya, pemerintah, dan masyarakat (Mendiknas, 2006).

Seleksi untuk masuk menjadi atlet binaan PPLP Kalimantan Selatan dibuka secara umum untuk semua golongan masyarakat. Tahapan yang harus diikuti oleh semua calon atlet PPLP yaitu seleksi administrasi, tes ketrampilan cabang olahraga, tes fisik, tes kesehatan, dan tes psikologi. Atlet yang lolos semua tahapan seleksi maka akan di asramakan untuk mendapat pembinaan dan latihan. Atlet yang lolos ini diharapkan bisa memberikan kontribusi bagi prestasi cabang olahraga untuk Kalimantan Selatan. Setiap atlet mendapatkan latihan dan pembinaan kedisiplinan, pendidikan etika dan moral. Maka, berdasarkan latar belakang di atas penulis sangat tertarik untuk mengetahui apakah tingkat kebugaran atlet pencak silat PPLP Kalimantan Selatan.

\section{METODE}

Metodologi penelitian merupakan bagian yang sangat penting dan syarat mutlak dari suatu penelitian. Seperti yang dikemukakan oleh (Sutrisno Hadi, 2000) bahwa metodologi penelitian sebagaimana yang dikenal sekarang untuk menjaga agar pengetahuan yang dicapai dari suatu penelitian dapat mempunyai harga ilmiah yang tinggi. Penelitian ini merupakan penelitian deskriptif kuantitatif dengan menggunakan metode survei melalui tes kebugaran yang diujikan kepada atlet pencak silat PPLP Kalimantan Selatan. Teknik pengambilan sampel pada penelitian ini menggunakan teknik total sampling. Sampel yang digunakan dalam penelitian ini yaitu 7 orang atlet pencak silat PPLP Kalimantan Selatan. Instrumen tes yang digunakan merujuk pada tes dan evaluasi perkembangan hasil latihan PPLP/SKO/PPLM dari Kemenpora. Tes yang digunakan pada cabang olahraga pencak silat meliputi tes anthropometri menggunakan index massa tubuh atlet, tes kecepatan menggunakan lari 20 meter dan lari 300 meter, tes kelincahan menggunakan shuttle run, tes daya ledak otot menggunakan standing board jump, tes kekuatan otot lengan menggunakan push up dan tes kekuatan otot perut menggunakan sit up, tes daya tahan menggunakan beep test (Kemenpora, 2014). Skor yang diperoleh dari hasil tes kemudian dianalisis dengan menggunakan teknik deskriptif kuantitatif dalam bentuk persentase. Teknik analisis data yang digunakan dalam penelitian ini menggunakan metode analisis deskriptif persentase seperti yang dikemukakan (Sudjana, 2001) dengan rumus :

$P=\frac{f}{N} \times 100 \%$

Keterangan :

$\mathrm{P}:$ persentase

$\mathrm{f}$ : frekuensi

$\mathrm{N}$ : jumlah responden

Dipublikasikan Oleh : 


\section{HASIL DAN PEMBAHASAN}

Peneliti melakukan penelitian pada bulan agustus 2020. Data yang penulis dapatkan selanjutnya dianalisis menggunakan rumus prosentase. Berdasarkan hasil analsis perhitungan data yang telah peneliti lakukan, diperoleh data sebagai berikut :

Tabel 1 Data Penelitian

\begin{tabular}{|c|c|c|c|c|c|c|c|c|}
\hline Nama & \multicolumn{2}{|c|}{ Speed } & Agility & Power & $\begin{array}{c}\text { MP } \\
\text { (lengan) }\end{array}$ & $\begin{array}{c}\text { MP } \\
\text { (perut) }\end{array}$ & Endurance & MMT \\
\hline CA & 3.14 & 4,14 & 13.00 & 2,38 & 62 & 41 & 9,3 & 18,3 \\
\hline SA & 4.19 & 5,19 & 13.25 & 1,50 & 60 & 30 & 6,2 & 21,9 \\
\hline PA & 3.41 & 4,41 & 14.00 & 1,88 & 58 & 31 & 6,10 & 19,8 \\
\hline $\mathrm{AM}$ & 3.35 & 4,35 & 12.05 & 2,18 & 65 & 45 & 7,10 & 20,1 \\
\hline $\mathrm{RA}$ & 3.38 & 4,38 & 13.50 & 2,58 & 75 & 43 & 8,10 & 20,5 \\
\hline $\mathrm{ED}$ & 4.02 & 5,02 & 13.45 & 1,81 & 56 & 44 & 6,9 & 20,2 \\
\hline $\mathrm{FW}$ & 3.90 & 4,9 & 12.50 & 1,8 & 71 & 42 & 6,9 & 20,3 \\
\hline
\end{tabular}

\section{Profil Kebugaran Jasmani}

1. Kriteria Index Masa Tubuh

Index masa tubuh adalah angka yang menjadi penilaian standar untuk menentukan kategori apa berat badan anda. Penggolongan kategorinya yaitu normal, kurang, berlebih, atau obesitas. Peneliti menggunakan rumus IMT untuk mengetahui penggolongan kriteria tubuh atlet.

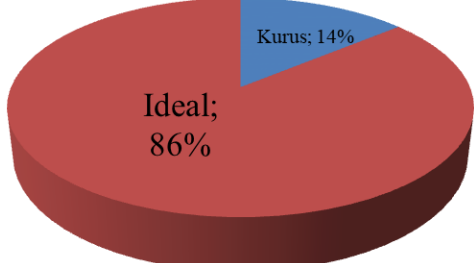

\section{Gambar 1 Kriteria Index Massa Tubuh Atlet Pencak Silat}

Dari diagram di atas dapat di simpulkan bahwa kategori tubuh atlet pencak silat PPLP sebanyak $86 \%$ ideal dan $14 \%$ kurus.

2. Kecepatan (speed)

Instrumen tes kecepatan yang digunakan dalam penelitian ini yaitu menggunakan tes lari 20 meter dan lari 300 meter.

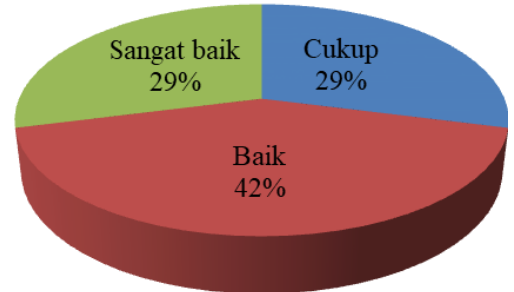

\section{Gambar 2 Hasil Tes Kecepatan Atlet Pencak Silat}

Dari diagram di atas dapat di simpulkan bahwa sebanyak $29 \%$ atlet pencak silat PPLP termasuk kategori sangat baik pada aspek kecepatan (speed), sebanyak 42\% termasuk kategori baik, dan sebanyak $29 \%$ termasuk kategori cukup.

3. Kelincahan

Instrumen tes kelincahan yang digunakan dalam penelitian ini yaitu menggunakan tes shuttle run.

\section{Dipublikasikan Oleh :}




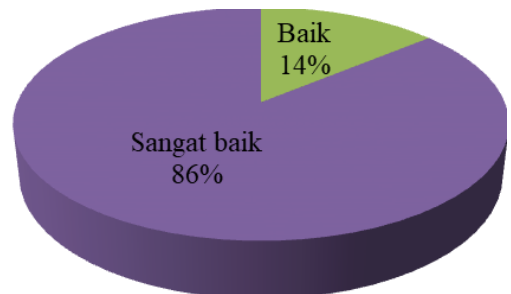

Gambar 3 Hasil Tes Kelincahan Atlet Pencak Silat

Dari diagram di atas dapat di simpulkan bahwa sebanyak 86\% atlet pencak silat PPLP termasuk kategori sangat baik pada aspek kelincahan (agility), dan sebanyak 14\% termasuk kategori baik.

4. Daya ledak otot (muscle power)

Instrumen tes kelincahan yang digunakan dalam penelitian ini yaitu menggunakan tes standing board jump.

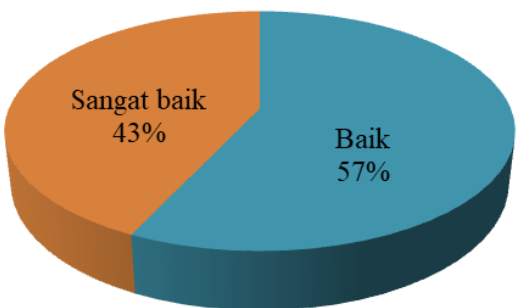

\section{Gambar 4 Hasil Tes Daya Ledak Otot Atlet Pencak Silat}

Dari diagram di atas dapat di simpulkan bahwa sebanyak 57\% atlet pencak silat PPLP termasuk kategori sangat baik pada aspek daya ledak otot (muscle power), dan sebanyak $47 \%$ termasuk kategori baik.

5. Kekuatan otot lengan

Instrumen tes kekuatan otot lengan yang digunakan dalam penelitian ini yaitu menggunakan tes push up.

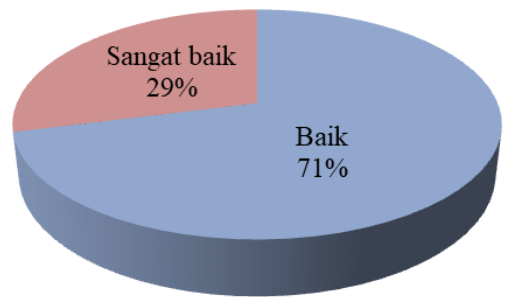

\section{Gambar 5 Hasil Tes Kekuatan Otot Lengan Atlet Pencak Silat}

Dari diagram di atas dapat di simpulkan bahwa sebanyak 29\% termasuk kategori sangat baik, dan sebanyak $71 \%$ atlet pencak silat PPLP termasuk kategori baik pada aspek kekuatan otot lengan.

6. Kekuatan otot perut

Instrumen tes kekuatan otot perut yang digunakan dalam penelitian ini yaitu menggunakan tes sit up.

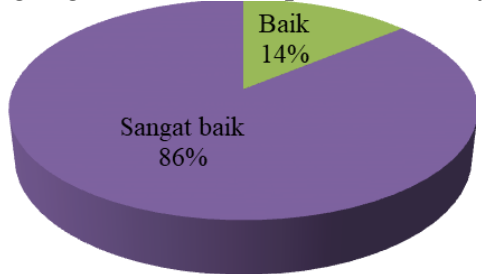

\section{Gambar 6 Hasil Tes Kekuatan Otot Perut Atlet Pencak Silat}

Dari diagram di atas dapat di simpulkan bahwa sebanyak 14\% atlet pencak silat PPLP termasuk kategori baik pada aspek kekuatan otot perut, sebanyak $86 \%$ termasuk kategori sangat baik.

7. Daya tahan (endurance)

Instrumen tes daya tahan (endurance) yang digunakan dalam penelitian ini yaitu menggunakan beep test. 


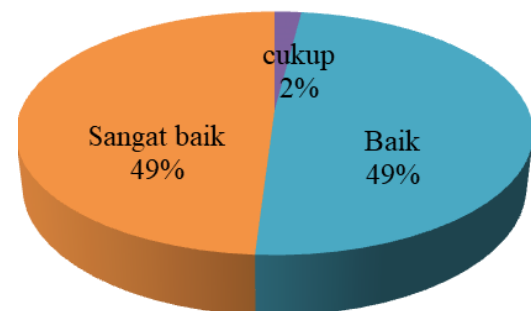

Gambar 7 Hasil Tes Daya Tahan Atlet Pencak Silat

Dari diagram di atas dapat di simpulkan bahwa sebanyak $2 \%$ atlet pencak silat PPLP termasuk kategori cukup pada aspek daya tahan (endurance), sebanyak 49\% termasuk kategori baik, dan sebanyak $49 \%$ termasuk kategori sangat baik.

Peneliti menggunakan analisis data deskriptif prosentase, dengan menggunakan rumus mean dan prosentase. Diperoleh kondisi fisik atlet pencak silat PPLP secara keseluruhan. Adapun hasil analisis datanya sebagai berikut:

Tabel 2 Kondisi Fisik Atlet Pencak Silat PPLP Secara Keseluruhan

\begin{tabular}{|l|c|c|c|c|c|c|c|c|}
\hline Nama & IMT & Speed & Agility & Power & $\begin{array}{c}\text { MP } \\
\text { (lengan) }\end{array}$ & $\begin{array}{c}\text { MP } \\
\text { (perut) }\end{array}$ & Endurance & Jumlah \\
\hline CA & 2 & 3 & 3 & 4 & 3 & 4 & 4 & 23 \\
\hline SA & 4 & 2 & 3 & 3 & 3 & 4 & 2 & 21 \\
\hline PA & 4 & 3 & 3 & 3 & 3 & 3 & 3 & 22 \\
\hline AM & 4 & 4 & 4 & 4 & 4 & 4 & 4 & 28 \\
\hline RA & 4 & 4 & 3 & 4 & 4 & 4 & 4 & 27 \\
\hline ED & 4 & 2 & 3 & 3 & 3 & 4 & 3 & 22 \\
\hline FW & 4 & 3 & 3 & 3 & 3 & 4 & 3 & 23 \\
\hline
\end{tabular}

Dari tabel di atas dapat diketahui bahwa kabugaran jasmani terbaik atas nama Am dengan jumlah skor keseluruhan yang diperoleh sebanyak 28 masuk pada kategori sangat baik. Secara keseluruhan, rata-rata kondisi kabugaran jasmani atlet pencak silat PPLP masuk pada kategori baik.

\section{PENUTUP}

Berdasarkan latar belakang masalah dan didukung oleh deskripsi teori serta analisis data, maka dapat disimpulkan bahwa profil kondisi kabugaran jasmani atlet pencak silat PPLP Kalimantan Selatan adalah sebagai berikut:

1. Kriteria index masa tubuh atlet pencak silat PPLP Kalsel sebanyak $86 \%$ masuk kategori ideal dan sebanyak $14 \%$ masuk kategori kurus.

2. Hasil tes kecepatan (speed) atlet pencak silat PPLP Kalsel sebanyak 29\% masuk kategori sangat baik, sebanyak $42 \%$ masuk kategori baik, dan sebanyak $29 \%$ masuk kategori cukup.

3. Hasil tes kelincahan atlet pencak silat PPLP Kalsel sebanyak 86\% masuk kategori sangat baik, dan sebanyak $14 \%$ masuk kategori baik.

4. Hasil tes daya ledak otot (muscle power) atlet pencak silat PPLP Kalsel sebanyak 57\% masuk kategori sangat baik, dan sebanyak $47 \%$ masuk kategori baik.

5. Hasil tes kekuatan otot lengan atlet pencak silat PPLP Kalsel sebanyak 29\% masuk kategori sangat baik, dan sebanyak $71 \%$ masuk kategori baik.

6. Hasil tes kekuatan otot perut atlet pencak silat PPLP Kalsel sebanyak $86 \%$ masuk kategori sangat baik, dan sebanyak $14 \%$ masuk kategori baik.

7. Hasil tes daya tahan (endurance) atlet pencak silat PPLP Kalsel sebanyak 49\% termasuk kategori sangat baik, sebanyak $49 \%$ termasuk kategori baik, dan sebanyak $2 \%$ masuk kategori cukup. 


\section{REFERENSI}

Departemen Pendidikan dan Kebudayaan (1996) 'Mengenal Pusat Kesegaran Jasmani dan Rekreasi', Pusat kesegaran dan Rekreasi, p. 4.

Departemen Pendidikan Nasional (2000) 'Pedoman Modul Pelatihan Kesehatan Olahraga Bagi Pelatih Olahragawan Pelajar', Pusat Pengembangan Kualitas Jasmani.

Djoko Pekik Irianto (2004) Bugar dan Sehat Dengan Berolahraga. Yogyakarta: Andi offset.

Dwi Bagus Subroto dan Achmad Rizanul Wahyudi (2017) 'Profil kondisi fisik atlet putra pencak silat SMP Muhammadiyah 2 Surabaya', Jurnal Unesa Surabaya.

Habibuddin Muhammad (2013) 'Profil Kondisi Fisik Mahasiswa UKM UNESA', Penkep FIK.

Harsono (1988) Coaching and Aspek-Aspek Psikologi dalam Coaching. Jakarta: Depdikbud.

Hasan Alwi (2008) Sejarah Perkembangan Pencak Silat. Yogyakarta: Andi Yogyakarta.

Kemenpora (2014) Petunjuk Pelaksanaan Tes dan Evaluasi Perkembangan Hasil Latihan PPLP/SKO/PPLM. 1 st edn. Edited by Asisten Deputi Sentra Olahraga Deputi Bidang Pembudayaan Olahraga. Jakarta:

Asisten Deputi Sentra Olahraga Deputi Bidang Pembudayaan Olahraga.

Khairul Hadziq (2017) Pendidikan Jasmani Olahraga dan Kesehatan. Bandung: Yama Widya.

Mendiknas (2006) Peraturan Menteri Pendidikan Nasional Nomor 34 tahun 2006 tentang pembinaan prestasi peserta didik. Jakarta.

Sucipto (2001) Pendekatan Keterampilan Taktis dalam Pembelajaran Pencak Silat Konsep dan Metode. Jakarta: Depdiknas.

Sudjana (2001) Metode Statistika. 6th edn. Bandung: Tarsito.

Suharjana (2013) Kebugaran Jasmani. Yogyakarta: Ilmu Keolahragaan UNY.

Sutrisno Hadi (2000) Methodology Research. 2nd edn. Yogyakarta: Yayasan Penerbitan Fakultas Psikologi UGM. 